Situs Jurnal : $\underline{\text { http://ejournal.stiepancasetia.ac.id/index.php/jieb }}$

Jilid 6 Nomor 3 November 2020

Hal 410 - 432

\title{
PENGARUH PENERAPAN GOOD GOVERNANCE DAN STANDAR AKUNTANSI PEMERINTAH TERHADAP AKUNTABILITAS KEUANGAN KECAMATAN DI KABUPATEN BARITO KUALA
}

\author{
Yudi Rahman*, Fauzi Firdaus
}

\begin{abstract}
ABSTRAK
Abstrak : Penelitian ini bertujuan untuk mengetahui dan menganalisis pengaruh secara simultan dan parsial Penerapan Good Governance dan Standar Akuntansi Pemerintah Terhadap Akuntabilitas Keuangan Kecamatan di Kabupaten Barito Kuala, serta mengetahui variabel yang berpengaruh dominan terhadap akuntabilitas keuangan Kecamatan di Kabupaten Barito Kuala. Dilihat dari Uji statistik F atau simultan menunjukkan semua variabel bebas yang dimasukkan dalam model mempunyai pengaruh secara bersama-sama terhadap variabel terikat, dan juga semua variabel berpengaruh signifikan secara parsial terhadap Akuntabilitas Keuangan Kecamatan Di Kabupaten Barito Kuala dapat diterima atau teruji berdasarkan hasil uji t. serta Dari hasil pengujian dapat diketahui berdasarkan uji t standarized coefficient variabel Standar Akuntansi Pemerintah berpengaruh dominan terhadap Akuntabilitas Keuangan.

Jenis dari penelitian yang digunakan peneliti adalah peneitian kuantitatif. Penelitian kuantitatif dilakukan dengan cara statistik, yakni menganalisa dengan berbagai dasar statistik dengan cara membaca tabel, grafik atau angka yang telah tersedia kemudian dilakukan beberapa uraian atau penafsiran dari data-data tersebut. Dalam penelitian ini populasi di 3 kecamatan sebanyak 102 pegawai dan di ambil sebanyak 82 sampel dengan menggunakan random sampling.Teknik pengumpulan data berupa dokumentasi, menyelidiki benda-benda tertulis seperti buku-buku, majalah, jurnal dan lain-lain, guna mendapatkan referensi untuk menjadi dasar dari penelitian, Disamping itu model yang digunakan untuk menganalisis adalah dengan Teknik analisis data yang terdiri dari uji validitas, realibilitas, uji asumsi klasik, regresi linier berganda serta uji hipotesa.

Hasil penelitian menunjukan pengaruh Secara Simultan Penerapan Good Governance Dan Standar Akuntansi Pemerintah Terhadap Akuntabilitas Keuangan Kecamatan Di Kabupaten Barito Kuala sehingga hipotesa pertama dapat diterima. Variabel Penerapan Good Governance berpengaruh signifikan terhadap Akuntabilitas Keuangan Kecamatan Di Kabupaten Barito Kuala secara parsial dan variabel Standar Akuntansi Pemerintah berpengaruh signifikan terhadap Akuntabilitas Keuangan Kecamatan Di Kabupaten Barito Kuala secara parsial sehingga hipotesa kedua dapat diterima. dan Dari hasil pengujian dapat diketahui Standar Akuntansi Pemerintah berpengaruh dominan terhadap Akuntabilitas Keuangan Kecamatan di Kabupaten Barito Kuala sehingga hipotesis ketiga dapat diterima.
\end{abstract}

Kata Kunci :Penerapan Good Governance, Standar Akuntansi Pemerintah, Akuntabilitas Keuangan 


\section{PENDAHULUAN}

\section{Latar Belakang}

Akuntansi mempunyai kaitan sangat erat dengan beberapa prinsip good governance, karena akuntansi pada hakekatnya adalah proses pencatatan secara sistematis atas transaksi keuangan yang bermuara kepada pelaporan keuangan daerah. Menurut Koiman (2014:273), governance merupakan serangkaian proses interaksi sosial politik antara pemerintah dengan masyarakat dalam berbagai bidang yang berkaitan dengan kepentingan masyarakat dan intervensi pemerintah atas kepentingan-kepentingan tersebut. Governance merupakan mekanismemekanisme, proses-proses dan institusiinstitusi melalui warga Negara mengarti kulasi kepentingan - kepentingan mereka, memediasi perbedaan- perbedaan mereka serta menggunakan hak dan kewajiban legal mereka. Partisipasi, transparansi dan akuntabilitas akan semakin membaik jika didukung oleh suatu sistem maupun laporan akuntansi yang menghasilkan informasi yang tepat waktu. fenomena yang harus di amati untuk dikembangkan dalam meningkatkan kesejahteraan dan kemakmuran rakyat saat ini yaitu tuntutan untuk organisasi yang bergerak di bidang jasa seperti pemerintah pusat dan daerah, unit - unit kerja pemerintah Daerah maupun lembaga-lembaga negara yang dituntut dalam melaksanakan akuntabilitas publik. Tuntutan dalam pengelolaan yang harus melakukan transparansi dan pertanggung jawaban atas menyusun, menyajikan, melaporkan dan pemberian informasi kepada publik sesuai pemenuhan hak-hak publik (Mardiasmo, 2013).

Penelitian ini sejalan dengan penelitian Fauzia Kartika Darmanto, 2017. Hasil penelitian menunjukan bahwa variabel good governance berpengaruh positif dan signifikan terhadap akuntabilitas keuangan, audit kinerja berpengaruh positif dan signifikan terhadap akuntabilitas keuangan, standar akuntansi pemerintah berpengaruh positif dan signifikan terhadap akuntabilitas keuangan. Perbedaan pada penelitian ini dengan menggunakan objek penelitian yang berbeda dan periode yang berbeda dan didukung juga oleh penelitian Elvira Zeyn, 2011. Dengan hasil penelitian menunjukkan implementasi itu pemerintahan yang baik tidak berpengaruh signifikan terhadap akuntabilitas keuangan; akuntansi implementasi standar pemerintah secara signifikan mempengaruhi akuntabilitas keuangan.

Good governance pada Kecamatan Barito Kuala diwajibakan menyusun laporan pertanggung jawaban yang menggunakan sistem akuntansi yang diatur oleh pemerintah pusat dalam bentuk Undang-undang dan Peraturan Pemerintah yang bersifat mengikat seluruh Pemerintah Daerah Khususnya kecamatan, oleh karena itu setiap kecamatan harus menyusun laporan keuangan sebaik mungkin. Keterbukaan merupakan data atau informasi bagi masyarakat yang dapat di akses sesuai peraturan perundang-undangan yang berlaku. Keterbukaan dapat juga menunjuk pada ketersediaan informasi dan kejelasan bagi masyarakat umum untuk mengetahui proses penyusunan, pelaksanaan, sertahasil yang telah dicapai melalui sebuah kebijakan public. Dan didukung oleh penelitian Verra Aprillia Nurussalam, Berdasarkan hasil penelitian ini, secara parsial dapat disimpulkan bahwa penerapan good governance berpengaruh signifikan terhadap kualitas laporan keuangan pemerintah daerah sebesar 23,8\% dan standar akuntansi pemerintahan berpengaruh signifikan terhadap kualitas laporan keuangan pemerintah daerah sebesar 35,9\%. Dari hasil penelitian tersebut diharapkan pemerintah daerah dapat meningkatkan lagi kualitas laporan keuangan pemerintah daerah dengan memenuhi prinsip-prinsip good governance dan sebaiknya harus tetap sesuai dengan standar akuntansi pemeritahan sebagai pedoman dalam penyajian laporan keuangan pemerintah daerah. Perbedaan pada penelitian ini dengan menggunakan objek penelitian yang berbeda dan periode 
yang berbeda. Obyek penelitian ini memilih pada Kantor Kecamatan di Kabupaten Barito Kuala. Dimana anggaran yang tersedia untuk setiap Satuan Kerja Perangkat Daerah (SKPD) pada setiap akhir tahun anggaran di lakukan evaluasi antara anggaran dengan realisasi. Maka peneliti tertarik untuk mengambil pada obyek tersebut untuk dilakukannya penelitian akuntabilitas dan transparansi. Upaya perbaikan di bidang penyajian pelaporan keuangan di Kecamatan Barito Kuala nampaknya belum dapat dilaksanakan sepenuhnya oleh Kantor Kecamatan Tabukan Kabupaten Barito Kuala. Ketidak mampuan laporan keuangan dalam melaksanakan akuntabilitas, tidak saja disebabkan karena laporan tahunan yang tidak memuat semua informasi relevan yang dibutuhkan para pengguna.

Pengelolaan keuangan sangat penting dilakukan di Kecamatan Kabupaten Barito Kuala agar anggaran ditetapkan untuk membiayai semua kebutuhan program yang dijalankan sertarealisasinya dapat sesuai dengan anggaran yang ditetapkan. Dalam kaitannya dengan penetapan anggaran tidak terlepas dari biaya-biaya yang berhubungan dengan program yang akan dilakukan oleh Kecamatan Tabukan Kabupaten Barito Kuala. Semua program membutuhkan biaya untuk menunjang program dari Kecamatan Tabukan Kabupaten Barito Kuala, untuk itu dibutuhkan pengalokasian biaya yang benar agar menghasilkan anggaran yang sesuai untuk kebutuhan tersebut. Berdasarkan uraian yang telah dikemukakan peneliti tertarik untuk melakukan penelitian pada instansi kecamatan dengan judul :Pengaruh Penerapan Good Governance dan Standar Akuntansi Pemerintah Terhadap Akuntabilitas Keuangan Kecamatan Di Kabupaten Barito Kuala

\section{Rumusan Masalah}

Berdasarkan latar belakang diatas, maka yang menjadi permasalahan dalam penelitian ini adalah:
1. Bagaimana pengaruh secara simultan Penerapan Good Governance dan Standar Akuntansi Pemerintah Terhadap Akuntabilitas Keuangan Kecamatan Di Kabupaten Barito Kuala?

2. Bagaimana pengaruh secara parsial Penerapan Good Governance dan Standar Akuntansi Pemerintah Terhadap Akuntabilitas Keuangan Kecamatan Di Kabupaten Barito Kuala?

3. Variabel manakah yang berpengaruh dominan terhadap Akuntabilitas Keuangan Kecamatan Di Kabupaten Barito Kuala?

\section{Batasan Masalah}

Berdasarkan latar belakang dan rumusan masalah, penelitian ini memfokuskan Pengaruh Penerapan Good Governance dan Standar Akuntansi Pemerintah Terhadap Akuntabilitas Keuangan Kecamatan Di Kabupaten Barito Kuala hanya pada tiga Kecamatan saja (Tabukan, Kuripan dan Marabahan).

\section{Tujuan Penelitian}

Adapun tujuan yang akan dicapaidalampenelitianini adalah untuk:

1. Untuk mengetahui dan menganalisis pengaruh secara simultan Penerapan Good Governance dan Standar Akuntansi Pemerintah Terhadap Akuntabilitas Keuangan Kecamatan di Kabupaten Barito Kuala

2. Untuk mengetahui dan menganalisis pengaruh secara parsial Penerapan Good Governance dan Standar Akuntansi Pemerintah Terhadap Akuntabilitas Keuangan Kecamatan di Kabupaten Barito Kuala.

3. Untuk mengetahui variabel yang berpengaruh dominan terhadap Akuntabilitas Keuangan Kecamatan di Kabupaten Barito Kuala 


\section{Manfaat Penelitian}

Hasil penelitian diharapkan dapat berguna bagi berbagai pihak, antara lain :

1. Aspek Pengembangan Ilmu

Bagi Penulis, untuk menambah pengetahuan tentang penelitian ilmiah yang dibahas dalambentuk laporan yang terstruktur secara sistematis dan menambah wawasan mengenai beberapa hal berkaitan dengan Penerapan Good Governance dan Standar Akuntansi Pemerintah Terhadap Akuntabilitas Keuangan Kecamatan di Kabupaten Barito Kuala

2. AspekTeoritis

Bagi Penelitilain, untuk menjadi sumber informasi dan referensi bagi penelitian mengenairealisasi anggaran.

3. AspekPraktis

Bagi Kecamatan Tabukan Kabupaten Barito Kuala untuk menjadi masukan dan sumbangan pemikiran sebagai salah satu bahan pertimbangan dalam menetapkan Penerapan Good Governance dan Standar Akuntansi Pemerintah dan Akuntabilitas Keuangan.

\section{TINJAUAN PUSTAKA}

\section{Akuntansi Sektor Publik}

Akuntansi pemerintahan adalah mekanisme teknik dan analisis akuntansi yang diterapkan pada pengelolaan dana masyarakat di lembaga-lembaga tinggi negara dan departemen-departemen di bawahnya Bastian (2012:3). Istilah sektor spublik memiliki pengertian yang bermacam-macam, hal ini merupakan konsekuensi dari luasnya wilayah publik, sehingga setiap disiplin ilmu (politik, ekonomi hukum dan sosial) memiliki cara pandang dan definisi yang berbeda-beda. Dari sudut pandang ekonomi sektor publik dapat dipahami sebagai suatu entitas (kesatuan) yang aktivitasnya berhubungan dengan usaha untuk menghasilkan barang dan pelayanan publik dalam rangka memenuhi kebutuhan dan hak publik.

1. Memberikan informasi yang diperlukan untuk mengelola secara tepat, efisien dan ekonomis atas alokasi suatu sumber daya yang dipercayakan kepada organisasi. Tujuan ini terkait dengan pengendalian manajemen.

2. Memberikan informasi yang memungkinkan bagi manajer untuk melaporkan pelaksanaan tanggung jawab secara tepat dan efektif program dan penggunaan sumberdaya yang menjadi wewenangnya dan memungkinkan bagi pegawai pemerintah untuk melaporkan kepada publik atas hasil operasi pemerintah dan penggunaan dana publik. Tujuan ini terkait dengan akuntabilitas

\section{Akuntansi Keuangan Daerah}

Pengertian keuangan daerah sebagaimana dimuat dalam penjelasan pasal 156 ayat 1 Undang-Undang Nomor 32 Tahun 2004 tentang Pemerintahan Daerah, adalah sebagai berikut: "Keuangan daerah adalah semua hak dan kewajiban daerah yang dapat dinilai dengan uang dan segala sesuatu berupa uang dan barang yang dapat dijadikan milik daerah yang berhubungan dengan pelaksanaan hak dan kewajiban tersebut" (Pusdiklatwas BPKP, 2007).

Faktor keuangan merupakan faktor yang paling dominan dalam mengukur tingkat kemampuan daerah dalam melaksanakan otonominya. Keadaan keuangan suatu daerah yang menentukan bentuk dan ragam yang akan dilakukan oleh pemerintah daerah. Salah satu kriteria penting untuk mengetahui secara nyata, kemampuan daerah untuk mengatur rumah tangganya sendiri adalah kemampuan "self supporting" dalam bidang keuangan. Halim (2013) mengungkapkan bahwa kemampuan 
Pemerintah Daerah dalam mengelola keuangan daerah dituangkan dalam Anggaran Pendapatan dan Belanja Daerah (APBD) yang langsung maupun tidak langsung. Selanjutnya untuk mengukur kemampuan keuangan Pemerintah Daerah adalah dengan melakukan analisis rasio keuangan terhadap APBD yang telah ditetapkan dan dilaksanakan.

\section{Good Governance (Pemerintahan Yang Baik)}

Menurut Koiman (2014:273), governance merupakan serangkaian proses interaksi sosial politik antara pemerintah dengan masyarakat dalam berbagai bidang yang berkaitan dengan kepentingan masyarakat dan intervensi pemerintah atas kepentingan-kepentingan tersebut. Governance merupakan mekanismemekanisme, proses-proses dan institusiinstitusi melalui warga Negara mengartikulasi kepentingan-kepentingan mereka, memediasi perbedaan- perbedaan mereka serta menggunakan hak dan kewajiban legal mereka. Governance merupakan proses lembaga-lembaga pelayanan , mengelola sumber daya publik dan menjamin realita hak azasi manusia. Dalam konteks ini good governance memiliki hakikat yang sesuai yaitu bebas dari penyalahgunaan wewenang dan korupsi serta dengan pengakuan hak yang berlandaskan pada pemerintahan hukum.

Menurut United Nation Development Program (UNDP) prinsip-prinsip yang dikembangkan dalam Tata Kelola Pemerintahan yang Baik (Good Governance) adalah sebagai berikut :

1. Partisipasi Setiap orang atau warga Negara memiliki hak suara yang sama dalam proses pengambilan keputusan, baik secara langsung maupun lembaga perwakilan,
2. Kepastian Hukum (Rule Of Law) Kerangka aturan hukum dan prundangan-undangan haruslah berkeadilan dan dapat ditegakkan serta dipatuhi secara utuh (impartialy), terutama tentang atuaran hukum dan hak azasi manusia.

3. Transparansi Transparansi harus dibangun dalam kerangka kebebasan aliran informasi berbagai proses, kelembagaan dan informasi harus dapat di akses secara bebas oleh mereka yang membutuhkannya dan harus dapat disediakan secara memadai dan mudah dimengerti sehingga dapat digunakan sebagai alat monitoring dan evaluasi.

4. Tanggung Jawab (Responsiveness) Setiap institusi dan prosesnya harus diarahkan pada upaya untuk melayani berbagai pihak yang berkepentingan.

5. Berorientasi Konsensus (Consensus Orientation) Pemerintahan yang Baik (Good Governance) akan bertindak sebagai penengah (mediator) bagi berbagai kepentingan yang berbeda untuk mencapai consensus atau kesepakatan yang terbaik bagi kepentingan masing-masing pihak.

6. Berkeadilan (Equity) Pemerintah yang Baik akan memberikan kesempatan yang sama baik terhadap laki-laki maupun perempuan dalam upaya mereka untuk meningkatkan dan memelihara kualitas hidupnya

7. Efektifitas dan Efisiensi Setiap proses kegiatan dan kelembagaan diarahkan untuk menghasilkan sesuatu yang benarbenar seusai dengan kebutuhan melalui pemanfaatan yang sebaik- baiknya dari berbagai sumber yang tersedia.

8. Akuntabilitas Para pengambil keputusan (Decision Maker) dalam organisasi sektor pelayanan dan warga Negara madani memiliki pertanggungjawaban (akuntabilitas) kepada public sebagaimana halnya kepada para pemilik (stakeholder).

9. Visi Strategis (Strategic Vision) Para pemimpin dan warga Negara memiliki perspektif yang luas dan jangka panjang

JIEB, Jilid 6, No 3, November 2020 ISSN Online 2615-2134 
tentang penyelenggaraan Pemerintahan yang Baik (Good Governance) dan pembangunan manusia, bersamaan dengan dirasakannya kebutuhan untuk pembangunan tersebut.

Menurut Koiman (2014:273), governance merupakan serangkaian proses interaksi sosial politik antara pemerintah dengan masyarakat dalam berbagai bidang yang berkaitan dengan kepentingan masyarakat dan intervensi pemerintah atas kepentingan-kepentingan tersebut. Governance merupakan mekanismemekanisme, proses-proses dan institusiinstitusi melalui warga Negara mengartikulasi kepentingan-kepentingan mereka, memediasi perbedaan- perbedaan mereka serta menggunakan hak dan kewajiban legal mereka. Governance merupakan proses lembaga-lembaga pelayanan , mengelola sumber daya publik dan menjamin realita hak azasi manusia. Dalam konteks ini good governance memiliki hakikat yang sesuai yaitu bebas dari penyalahgunaan wewenang dan korupsi serta dengan pengakuan hak yang berlandaskan pada pemerintahan hukum. Adapun indikator sebagai berikut :

\section{Partisipasi}

Setiap orang atau warga Negara memiliki hak suara yang sama dalam proses pengambilan keputusan, baik secara langsung maupun lembaga perwakilan, sesuai dengan kepentingan dan aspirasi masing-masing. Partisipasi yang luas ini perlu dibangun dalam suatu tatanan kebebasan berserikat dan berpendapat, serta kebebasan untuk berpartisipasi secara konstruktif.

2. Transparansi

Transparansi harus dibangun dalam kerangka kebebasan aliran informasi berbagai proses, kelembagaan dan informasi harus dapat di akses secara bebas oleh mereka yang membutuhkannya dan harus dapat disediakan secara memadai dan mudah dimengerti sehingga dapat digunakan sebagai alat monitoring dan evaluasi.

3. Tanggung Jawab

Setiap institusi dan prosesnya harus diarahkan pada upaya untuk melayani berbagai pihak yang berkepentingan. Keselarasan antara program dan kegiatan pelayanan yang diberikan oleh organisasi publik dengan kebutuhan dan keinginan masyarakat yang diprogramkan dan dijalankan oleh organisasi publik, maka kinerja organisasi tersebut akan semakin baik. Responsivitas yang sangat rendah ditunjukkan dengan ketidak selarasan antara pelayanan dan kebutuhan masyarakat. Hal tersebut jelas menunjukkan kegagagalan organisasi dalam mewujudkan misi dan tujuan organisasi publik.

4. Berkeadilan (Equity)

Pemerintah yang Baik akan memberikan kesempatan yang sama baik terhadap laki-laki maupun perempuan dalam upaya mereka untuk meningkatkan dan memelihara kualitas hidupnya

5. Efektifitas dan Efisiensi

Setiap proses kegiatan dan kelembagaan diarahkan untuk menghasilkan sesuatu yang benar-benar seusai dengan kebutuhan melalui pemanfaatan yang sebaik- baiknya dari berbagai sumber yang tersedia.

\section{Standar Akuntansi Pemerintah}

Peraturan Pemerintah Nomor 71 tahun 2010 tentang Standar Akuntansi Pemerintahan pasal 9 menyatakan bahwa dengan diberlakukannya peraturan ini maka Peraturan Pemerintah Nomor 24 tahun 2005 tentang Standar Akuntansi Pemerintahan dicabut dan dinyatakan tidak berlaku. Dengan demikian, Peraturan Pemerintahan Nomor 71 tahun 2010 tentang Standar Akuntansi Pemerintahan telah 
menggantikan Peraturan Pemerintah Nomor 24 tahun 2005 tentang Standar Akuntansi Pemerintahan. Pengertian Standar Akuntansi Pemerintahan terdapat dalam Peraturan Pemerintah Nomor 71 tahun 2010 yang berbunyi: "Standar Akuntansi Pemerintah yang selanjutnya disebut SAP adalah prinsip-prinsip akuntansi yang diterapkan dalam menyusun dan menyajikan laporan keuangan pemerintah".

Berdasarkan hal tersebut laporan keuangan sektor publiknya meliputi:

1. Laporan Realisasi Anggaran

2. Neraca

3. Laporan Arus Kas

4. Catatan atas Laporan Keuangan

\section{Akuntabilitas Keuangan}

Akuntabilitas dapat diartikan sebagai bentuk kewajiban mempertanggungjawabkan keberhasilan atau kegagalan pelaksanaan organisasi dalam mencapai tujuan dan sasaran yang telah ditetapkan sebelumnya, melalui suatu media pertanggung jawaban yang dilaksanakan secara periodik. Definisi akuntabilitas publik menurut Penny Kusumastuti (2014:2) adalah sebagai berikut : "Akuntabilitas adalah bentuk kewajiban penyedia penyelenggaraan kegiatan publik untuk dapat menjelaskan dan menjawab segala hal menyangkut langkah dari seluruh keputusan dan proses yang dilakukan, serta pertanggungjawaban terhadap hasil kinerjanya."

Dalam teknis dan pelaksanaan akuntabilitas publik diperlukan untuk memperhatikan prinsip-prinsip akuntabilitas menurut LAN dan BPKP,Modul I (2013:43) yaitu sebagai berikut :

1. Harus ada komitmen dari pimpinan dan seluruh staff instansi untuk melakukan pengelolaan pelaksanaan misi agar akuntabel.

2. Harus merupakan suatu sistem yang dapat menjamin penggunaan sumbersumber daya secara konsisten dengan peraturan perundang-undangan yang berlaku.

3. Harus dapat menunjukkan tingkat pencapaian tujuan dan sasaran yang ditetapkan.

4. Harus berorientasi pada pencapaian visi dan misi serta hasil dan manfaat yang diperoleh, harus jujur, objektif, transparan dan inovatif sebagai katalisator perubahan manajemen dalam bentuk pemutakhiran metode dan teknik pengukuran kinerja dan penyusunan laporan akuntabilitas.

Menurut Abdul Halim (2012:20) definisi akuntabilitas publik sebagai berikut: Kewajiban untuk memberikan pertanggungjawaban serta menerangkan kinerja dan tindakan seseorang, badan hukum atau pimpinan organisasi kepada pihak yang lain yang memiliki hak dan kewajiban untuk meminta kewajiban pertanggungjawaban dan keterangan." Berikut indikator pada variabel ini :

1. Akuntabilitas Hukum dan Kejujuran Akuntabilitas hukum dan kejujuran adalah akuntabilitas lembaga-lembaga publik untuk berperilaku jujur dalam bekerja dan menaati ketentuan hukum yang berlaku. Penggunaan dana publik harus dilakukan secara benar dan telah mendapatkan otorisasi. Akuntabilitas hukum berkaitan dengan kepatuhan terhadap hukum dan peraturan lain yang disyaratkan dalam menjalankan organisasi, sedangkan akuntabilitas kejujuran berkaitan dengan penghindaran penyalahgunaan jabatan (abuse of power), korupsi dan kolusi. Akuntabilitas hukum menuntut penegakan hukum (law of enforcement), sedangkan akuntabilitas kejujuran menuntut adanya praktik organisasi yang 
sehat tidak terjadi malpraktik dan maladministrasi.

2. Akuntabilitas Manajerial

Akuntabilitas Manajerial adalah pertanggung jawaban lembaga publik untuk melakukan pengelolaan organisasi secara efisien dan efektif. Akuntabilitas manajerial dapat juga diartikan sebagai akuntabilitas kinerja (performance accountability). Inefisiensi organisasi publik adalah menjadi tanggung jawab lembaga yang bersangkutan dan tidak boleh dibebankan kepada klien atau customer-nya. Akuntabilitas manajerial merupakan akuntabilitas bawahan kepada atasan dalam suatu organisasi.

3. Akuntabilitas Program

Akuntabilitas program berkaitan dengan pertimbangan apakah tujuan yang ditetapkan dapat dicapai atau tidak, dan apakah telah mempertimbangkan alternatif program yang memberikan alternatif program yang memberikan hasil yang optimal dengan biaya yang minimal. Dengan kata lain akuntabilitas program berarti bahwa programprogram organisasi hendaknya merupakan program yang bermutu yang mendukung strategi dan pencapaian misi, visi, dan tujuan organisasi.

4. Akuntabilitas Kebijakan

Akuntabilitas kebijakan terkait dengan pertanggung jawaban lembaga publik atas kebijakan-kebijakan yang diambil. Lembaga-lembaga publik hendaknya dapat mempertanggungjawabkan kebijakan yang telah ditetapkan dengan mempertimbangkan dampak di masa depan. Dalam membuat kebijakan harus dipertimbangkan apa tujuan kebijakan tersebut, mengapa kebijakan itu diambil siapa sasarannya, pemangku kepentingan (stakeholder) mana yang akan terpengaruh dan memperoleh manfaat dan dampak (negatif) atas kebijakan tersebut.

5. Akuntabilitas Finansial
Akuntabilitas ini merupakan pertanggung jawaban lembaga-lembaga publik untuk menggunakan dana publik (public money) secara ekonomis, efisien, dan efektif, tidak ada pemborosan dan kebocoran dana, serta korupsi. Akuntabilitas Finansial ini sangat penting karena menjadi sorotan utama masyarakat. Akuntabilitas ini mengaharuskan lembaga-lembaga publik untuk membuat laporan keuangan untuk menggambarkan kinerja finansial organisasi kepada pihak luar

\section{Aturan-Aturan}

Peraturan Presiden Republik Indonesia Nomor 29 Tahun 2014 Tentang Sistem Akuntabilitas Kinerja Instansi Pemerintah Dengan Rahmat Tuhan Yang Maha Esa Presiden Republik Indonesia, Menimbang: bahwa untuk melaksanakan ketentuan Pasal 20 ayat (3) Peraturan Pemerintah Nomor 8 Tahun 2006 tentang Pelaporan Keuangan dan Kinerja Instansi Pemerintah, perlu menetapkan Peraturan Presiden tentang Sistem Akuntabilitas Kinerja Instansi Pemerintah. Mengingat: 1. Pasal 4 ayat (1) Undang-Undang Dasar Negara Republik Indonesia Tahun 1945; BAB I KETENTUAN UMUM Pasal 1 Dalam Peraturan Presiden ini yang dimaksud dengan:

1. Sistem Akuntabilitas Kinerja Instansi Pemerintah, yang selanjutnya disingkat SAKIP, adalah rangkaian sistematik dari berbagai aktivitas, alat, dan prosedur yang dirancang untuk tujuan penetapan dan pengukuran, pengumpulan data, pengklasifikasian, pengikhtisaran, dan pelaporan kinerja pada instansi pemerintah, dalam rangka pertanggung jawaban dan peningkatan kinerja instansi pemerintah.

2. Indikator Kinerja adalah ukuran keberhasilan yang akan dicapai dari kinerja program dan kegiatan yang telah

JIEB, Jilid 6, No 3, November 2020 ISSN Online 2615-2134 
direncanakan. 8. Indikator Kinerja Program adalah ukuran atas hasil (outcome) dari suatu program yang merupakan pelaksanaan tugas pokok dan fungsi suatu kementerian negara/lembaga dan pemerintah daerah yang dilaksanakan oleh satuan kerja/SKPD.

3. Akuntabilitas Kinerja adalah perwujudan kewajiban suatu instansi pemerintah untuk mempertanggung jawabkan keberhasilan atau kegagalan pelaksanaan Program dan Kegiatan yang telah diamanatkan para pemangku kepentingan dalam rangka mencapai misi organisasi secara terukur dengan sasaran/target Kinerja yang telah ditetapkan melalui laporan kinerja instansi pemerintah yang disusun secara periodik.

4. Entitas Akuntabilitas Kinerja Satuan Kerja adalah unit instansi pemerintah pusat selaku kuasa pengguna anggaran yang melakukan kegiatan pencatatan, pengolahan, dan pelaporan data Kinerja. 16. Entitas Akuntabilitas Kinerja Unit Organisasi adalah unit instansi pemerintah pusat yang melakukan pencatatan, pengolahan, pengikhtisaran, dan pelaporan data kinerja tingkat eselon 1

5. Satuan Kerja Perangkat Daerah yang selanjutnya disingkat SKPD adalah perangkat daerah pada pemerintah daerah selaku pengguna anggaran/barang.

6. Sistem Akuntansi Pemerintahan adalah rangkaian sistematik dari prosedur, penyelenggara, peralatan, dan elemen lain untuk mewujudkan fungsi akuntansi sejak analisis transaksi sampai dengan pelaporan keuangan di lingkungan organisasi pemerintah.

\section{Penelitian Terdahulu}

1. Fauzia Kartika Darmanto, Pengaruh Penerapan Good Governance, Audit Kinerja Dan Standar Akuntansi Pemerintah Terhadap Akuntabilitas Keuangan Pemerintah Daerah Kabupaten Karanganyar, 2017,Penelitian ini dilakukan pada Satuan Kerja Perangkat Daerah Karanganyar. Penentuan sampel dalam penelitian ini menggunakan metode purposive sampling dan penentuan sampel untuk tiap SKPD ditentukan secara proporsional. Teknik Analisa data kuantitatif, karena data yang digunakan berbentuk angka-angka.. Pengujian yang digunakan dalam penelitian ini adalah analisis regresi linier berganda dengan bantuan SPSS menggunakan uji t dan uji F. Hasil penelitian menunjukan bahwa variabel good governance berpengaruh positif dan signifikan terhadap akuntabilitas keuangan, audit kinerja berpengaruh positif dan signifikan terhadap akuntabilitas keuangan, standar akuntansi pemerintah berpengaruh positif dan signifikan terhadap akuntabilitas keuangan. Perbedaan pada penelitian ini dengan menggunakan objek penelitian yang berbeda dan periode yang berbeda.

2. Elvira Zeyn, Pengaruh Penerapan Good Governance dan Standar Akuntansi Pemerintahan terhadap Akuntabilitas Keuangan, 2011. Populasi penelitian ini adalah Satuan Kerja Perangkat Daerah (SKPD) sebagai pengguna anggaran pada Pemda Kabupaten Sukamara Provinsi Kalimantan Tengah. Pengambilan sampel dilakukan dengan cara stratified random sampling yaitu pengambilan sampel yang dilakukan bertahap dengan strata (Uma Sekaran, 133:2006). Jumlah sampel penelitian 
sebanyak 18 Kepala SKPD. Penelitian ini menggunakan metode survey yang terdiri dari descriptive survey dan explanatory survey dengan investigation type yang bersifat kausalitas. Pendekatan penelitian yang dilakukan dengan metode Perbedaan pada penelitian ini dengan menggunakan objek penelitian yang berbeda dan periode yang berbeda.

\section{Hipotesis Penelitian}

Hipotesis dalam penelitian ini.

H1 Diduga secara simultan variabel Penerapan Good Governance dan Standar Akuntansi Pemerintah (SAP) berpengaruh Terhadap variabel Akuntabilitas Keuangan Kecamatan di Kabupaten Barito Kuala

H2 Diduga secara parsial variabel Penerapan Good Governance dan Standar Akuntansi Pemerintah (SAP) berpengaruh Terhadap variable Akuntabilitas Keuangan Kecamatan di Kabupaten Barito Kuala

H3 Diduga variabel Penerapan Standar Akuntansi Pemerintah (SAP) berpengaruh dominan Terhadap variabel Akuntabilitas Keuangan Kecamatan di Kabupaten Barito Kuala.

\section{METODE PENELITIAN}

\section{JenisPenelitian}

Penelitian ini termasuk penelitian kuantitatif. Penelitian kuantitatif dilakukan dengan cara statistik, yakni menganalisa dengan berbagai dasar statistik.Selain itu Penelitian korelasional, penelitian korelasi suatu penelitian dengan cara mengumpulkan sejumlah data untuk melihat apakah terdapat suatu keterkaitan antara suatu variabel dengan variabel lainya. Penelitian korelasional bertujuan untuk menjelaskan hubungan kausalitas tersebut maka rancangan penelitian ini menggunakan metode explanatory research. Adapun model analisis yang digunakan adalah analisis regresi linier berganda. Tujuan dari penelitian ini untuk mengetahui pengaruh Penerapan Good Governance Dan Standar Akuntansi Pemerintah Terhadap Akuntabilitas Keuangan Kecamatan Di Kabupaten Barito Kuala.

\section{Populasi dan Ukuran Sampel}

Sugiyono (2014: 117) populasi merupakan wilayah generalisasi yang terdiri atas objek/subjek yang mempunyai kualitas dan karakteristik tertentu yang ditetapkan oleh peneliti untuk dipelajari dan kemudian ditarik kesimpulannya. Populasi pada penelitian beberapa pegawai 3 Kecamatan di Kabupaten Barito Kuala. Berikut data pegawai 3 Kecamatan di Kabupaten Barito Kuala yang berjumlah 102 populasi.

Sampel adalah sebagian dari jumlah dan karakteristik yang dimiliki oleh populasi tersebut.Pada penelitian ini yang dijadikan sampel penelitian adalah pegawai 3 Kecamatan dan juga kadesdi Kabupaten Barito Kuala. Jumlah pegawai beserta kades di Kecamatan Tabukan berjumlah 28 orang, kemudian jumlah pegawai dan juga kades di Kecamatan Marabahan Berjumlah 31, kemudian jumlah pegawai dan juga kades di kecamatan Kuripan berjumlah 23. Jadi berdasarkan data di atas jumlah sampel pada penelitian ini adalah $28+31+23=82$, dengan demikian sampel pada penelitian ini berjumlah 82 responden.

\section{Variabel dan Definisi Operasional Variabel}

1. Variabel Terikat (dependent)

Variabel terikat adalah variabel yang menjadi pusat perhatan utama peneliti. Sebuah masalah akan sangat mudah

JIEB, Jilid 6, No 3, November 2020 ISSN Online 2615-2134 
terlihat dengan mengenali berbagai variabel terikat yang digunakan dalam sebuah model. Dalam penelitian ini yang menjadi variabel terikat adalah Akuntabilitas Keuangan (Y).

2. Variabel Bebas (independent)

Variabel bebas adalah variabel yang mempengaruhi variabel terikat, baik yang pengaruhnya positif maupun yang pengaruhnya negatif. Dalam penelitian ini yang menjadi variabel bebas adalah Good Governance (X1) dan Standar Akuntansi Pemerintah (X2).

\section{Definisi Operasional Variabel}

Berikut indikator pada variabel ini :

\section{A. Akuntabilitas Keuangan $(Y)$}

Menurut Abdul Halim (2012:20) definisi akuntabilitas keuangan adalah Kewajiban untuk memberikan pertanggungjawaban serta menerangkan kinerja dan tindakan seseorang, badan hukum atau pimpinan organisasi kepada pihak yang lain yang memiliki hak dan kewajiban untuk meminta kewajiban. pertanggungjawaban dan keterangan, indikatornya adalah :

1. Akuntabilitas Hukum dan Kejujuran Akuntabilitas hukum dan kejujuran adalah akuntabilitas lembagalembaga publik untuk berperilaku jujur dalam bekerja dan menaati ketentuan hukum yang berlaku. Penggunaan dana publik harus dilakukan secara benar dan telah mendapatkan otorisasi.

2. Akuntabilitas Manajerial

Akuntabilitas Manajerial adalah pertanggung jawaban lembaga publik untuk melakukan pengelolaan organisasi secara efisien dan efektif.

3. Akuntabilitas Program

Akuntabilitas program berkaitan dengan pertimbangan apakah tujuan yang ditetapkan dapat dicapai atau tidak, dan apakah telah mempertimbangkan alternatif program yang memberikan alternatif program yang memberikan hasil yang optimal dengan biaya yang minimal.

4. Akuntabilitas Kebijakan

Akuntabilitaskebijakan terkait dengan pertanggungjawaban lembaga publik atas kebijakan-kebijakan yang diambil.

5. Akuntabilitas Finansial

Akuntabilitas ini merupakan pertanggungjawaban lembagalembaga publik untuk menggunakan dana publik (public money) secara ekonomis, efisien, dan efektif, tidak ada pemborosan dan kebocoran dana, serta korupsi.

B. Good Governance(X1)

Menurut Koiman (2014:273), governance merupakan serangkaian proses interaksi sosial politik antara pemerintah dengan masyarakat dalam berbagai bidang yang berkaitan dengan kepentingan masyarakat dan intervensi pemerintah atas kepentingankepentingan tersebut.

Adapun indikator sebagai berikut :

1. Partisipasi

2. Transparansi

3. TanggungJawab

4. Berkeadilan (Equity)

5. Efektifitas dan Efisiensi

C. Standar Akuntansi Pemerintah X2 Pengertian Standar Akuntansi Pemerintahan terdapat dalam Peraturan Pemerintah Nomor 71 tahun 2010 yang berbunyi: Standar Akuntansi Pemerintah yang selanjutnya disebut SAP adalah prinsip-prinsip akuntansi yang diterapkan dalam menyusun dan menyajikan laporan keuangan 
pemerintah. Indikator pada variabel ini sebagai berikut :

1. Laporan Realisasi Anggaran

2. Neraca

3. Laporan Arus Kas

4.Catatan atas Laporan Keuangan

\section{Teknik Analisis Data}

Untuk penelitian yang tidak merumuskan hipotesis, langkah terakhir tidak dilakukan.

\section{Uji Instrumen Penelitian}

a. Uji Validitas.

Dalam penelitian ini, validitas instrument penelitian dilakukan dengan melihat angka signifikasi yaitu membandingkan nilai $\mathrm{r}$ hitung (corrected item-total correlation) dengan tabel untuk degree of freedom (df) $=\mathrm{n}-2$. Kuesioner dinyatakan vallid apabila nilai lebih kecil dari 0,005

b. Uji Reliabilitas

Uji realiabilitas digunakan untuk mengukur kehandalan indikator. Jika angka reliabilitas Alpha Cronbach > 0,6 atau lebih besar dari 0,6, maka item variabel tersebut dinyatakan reliabel (Ferdinand,2013).

\section{Uji Asumsi Klasik}

Beberapa uji penyimpangan asumsi klasik yang perlu dilakukan dalam analisi jalur, antara lain (Ferdinand,2013) :

a. Uji Normalitas

Uji normalitas bertujuan untuk menguji apakah dalam model regresi, variabel pengganggu atau residual memiliki distribusi normal.
1) Jika data menyebar disekitar garis diagonal dan mengikuti arah garis diagonal atau grafik histogramnya menunjukkan distribusi normal, maka model regresi memenuhi asumsi normalitas.

2) Jika data menyebar jauh dari diagonal atau tidak mengikuti arah garis diagonal atau grafik histogram tidak menunjukkan distribusi normal, maka model regresi tidak memenuhi asumsi normalitas.

b. Uji Heterokedastisitas

Model regresi yang baik adalah homoskedastisitas atau tidak terjadi heteroskedastisitas. Cara untuk mendeteksi dengan cara melihat grafik scatter plot antara nilai prediksi variabel terikat (ZPRED) dengan residual (SRESID). Dasar analisis:

c. Uji Multikolinieritas

Uji multikolineritas bertujuan menguji apakah dalam model regresi linier berganda ditemukan adanya korelasi antar variabel bebas model regresi yang baik seharusnya tidak terjadi korelasi diantara variabel bebas jika variabel bebas berkorelasi maka variabel-variabel ini tidak ortogonal. Variabel ortogonal adalah variabel bebas yang nilai korelasi antar sesama variabel bebas $=0$. Multikolineritas dapat dilihat dari nilai Tolerance dan Variance Inflation Factor (VIF).

d. Uji Autokorelasi

Secara garis besar, uji autokorelasi digunakan untuk mendeteksi apakah terjadi korelasi antara residu pada periode saat ini ( $\mathrm{t}$ ) dengan residu pada periode satu periode sebelumnya ( $t$ 1). Untuk memenuhi kriteria BLUE, model regresi harus terbebas dari 
gejala autokorelasi. Khususnya masalah autokorelasi cenderung terjadi pada penelitian dengan menggunakan data Time Series, sementara itu sangat jarang terjadi pada penelitian dengan menggunakan data Cross Section. Ghozali ( 2014) mengungkapkan bahwa untuk mendeteksi gejala autokorelasi dapat menggunakan uji statistik yaitu uji Durbin-Watson dengan kriteria pengambilan keputusan sebagai berikut:

\section{Analisis Regresi Linier Berganda}

Model regresi linier berganda adalah model yang digunakan untuk menganalisis pengaruh dari berbagai variabel independen terhadap satu variabel dependen (Ferdinand,2013) Formula untuk regresi linear berganda adalah sebagai berikut:

Rumus $=\mathrm{Y}=\mathrm{a}+\mathrm{b}_{1} \mathrm{X}_{1} \mathrm{~b}_{2} \mathrm{X}_{2}+\mathrm{e}$

Keterangan :

$\mathrm{Y}=$ Akuntabilitas Keuangan

$\mathrm{a}=$ Konstanta

$\mathrm{X}_{1}=$ Penerapan Good Governance

$\mathrm{X}_{2}=$ Standar Akuntansi Pemerintah

$\mathrm{b}_{1}, \mathrm{~b}_{2}=$ Koefisien Regresi

$\mathrm{e} \quad=$ Eror

\section{Uji Hipotesis}

a. Uji F Signifikasi

Uji statistik $F$ pada dasarnya menunjukkan apakah semua variabel independen atau bebas yang dimasukkan dalam model mempunyai pengaruh secara bersamasama terhadap variabel dependen atau terikat. Adapun kriteria pengujian uji $\mathrm{F}$ adalah sebagai berikut: Pengujian menggunakan signifikansi lebih kecil dari 0,05 dan membandingkan antara nilai kritis $\mathrm{F}$ tabel dengan $\mathrm{F}$ hitung. Jika $\mathrm{F}$ hitung $\leq \mathrm{F}$, $\mathrm{F}$ hitung lebih kecil dari $\mathrm{F}$ tabel maka Ho diterima, yang berarti variabel independen tidak berpengaruh terhadap perubahan nilai variabel dependen. Sedangkan jika $\mathrm{F}$ hitung $>\mathrm{F}$ tabel, $\mathrm{F}$ hitung lebih besar dari $\mathrm{F}$ tabel maka Ho ditolak dan menerima $\mathrm{Ha}$, ini berarti semua variabel independen secara bersama-sama berpengaruh terhadap nilai variabel dependen (Duwi Priyatno, 2014: 180)

b. Uji t Signifikansi

Uji t adalah pengujian signifikansi untuk mengetahui apakah masing-masing variabel bebas berpengaruh secara signifikan terhadap variabel dependen. Pengambilan keputusan dilakukan berdasarkan perbandingan nilai t hitung masing - masing koefisien dengan $\mathrm{t}$ tabel, dengan tingkat signifikan 5\%. Jika $\mathrm{t}$ hitung $<\mathrm{t}$ tabel maka Ho diterima, ini berarti variabel independen tidak berpengaruh terhadap nilai variabel dependen. Sedangkan jika $t$ hitung $>t$ tabel maka Ho ditolak dan menerima Ha, ini berarti variabel independen berpengaruh terhadap variabel dependen (Duwi Priyatno, 2017: 184)

c. Uji Koefisien Determinasi $\left(\mathrm{R}^{2}\right)$

Koefisien Determinasi $\left(R^{2}\right)$ digunakan untuk mengetahui seberapa jauh kemampuan suatu model penelitian dalam menjelaskan variasi variabel dependen yang ada. Dengan demikian akan diketahui seberapa besar variabel dependen dapat diterangkan oleh variabel independen yang ada. Nilai yang mendekati angka 1 berarti variabel independen hampir atau mampu memberikan informasi yang dibutuhkan untuk memprediksi variasi dependen (Ghozali, 2014).

\section{Data Uji Instrumen \\ 1. Uji Validitas}


Pada pengujian ini diutamakan untuk mengukur sah atau valid tidaknya suatu kuesioner dilakukan pengujian Validitas. Suatu kuesioner dikatakan valid jika pertanyaan pada kuesioner tersebut mampu untuk mengungkap sesuatu yang akan diukur olehkuesioner tersebut.Pengujian validitas pada penelitian ini dilakukan dengan cara menghitung korelasi skor masing-masing butir pertanyaan dengan skor total seluruh butir pertanyaan. Suatu butir pertanyaan adalah valid jika terdapat korelasi yang signifikan yang ditunjukkan dengan nilai signifikansi yang kurang dari nilai $a=0,05$. Hasil uji validitas pertanyaan dapat penulis disajikan pada tabel sebagai berikut :

Tabel 4.1

Hasil Uji Validitas

Good Governance

\begin{tabular}{|c|c|c|c|c|}
\hline $\begin{array}{c}\text { Variab } \\
\text { el }\end{array}$ & $\begin{array}{c}\text { Ite } \\
\text { m }\end{array}$ & $\begin{array}{c}\text { Correl } \\
\text { ation }\end{array}$ & Sig & $\begin{array}{c}\text { Ketera } \\
\text { ngan }\end{array}$ \\
\hline $\begin{array}{c}\text { Good } \\
\text { Govern } \\
\text { ance } \\
\text { (X1) }\end{array}$ & $\mathrm{X} 1$ & 0,922 & 0,0 & Valid \\
.1 & $\mathrm{X} 1$ & 0,920 & 0,0 & Valid \\
\cline { 2 - 5 } & $\mathrm{X} 1$ & 0,920 & 0,0 & Valid \\
\cline { 2 - 5 } & .3 & & 00 & \\
\cline { 2 - 5 } & $\mathrm{X} 1$ & 0,924 & 0,0 & Valid \\
& .4 & & 00 & \\
\cline { 2 - 5 } & $\mathrm{X} 1$ \\
& 0,902 & 0,0 & Valid \\
& .5 & & 00 & \\
\cline { 2 - 5 } & $\mathrm{X} 1$ & 0,912 & 0,0 & Valid \\
.6 & & 00 & \\
\hline
\end{tabular}

Sumber : Data Diolah 2019

Berdasarkan hasil uji validitas dapat diketahui bahwa seluruh butir item pertanyaan memiliki nilai signifikansi lebih kecil dari 0,05, dengan demikian dapat dikatakan bahwa seluruh butir pertanyaan Good Governanceadalah valid.

Tabel 4.2
Hasil Uji Validitas

Standar Akuntansi Pemerintah

\begin{tabular}{|c|c|c|c|c|}
\hline Variabel & Item & Correlatio & Sig & Ket \\
\hline \multirow{13}{*}{$\begin{array}{l}\text { Standar } \\
\text { Akuntansi } \\
\text { Pemerinta } \\
\text { h (X2) }\end{array}$} & $\mathrm{X} 2.1$ & 0,743 & $\begin{array}{c}0,00 \\
0\end{array}$ & Valid \\
\hline & $\mathrm{X} 2.2$ & 0,712 & $\begin{array}{c}0,00 \\
0\end{array}$ & Valid \\
\hline & $\mathrm{X} 2.3$ & 0,682 & $\begin{array}{c}0,00 \\
0\end{array}$ & Valid \\
\hline & $\mathrm{X} 2.4$ & 0,673 & $\begin{array}{c}0,00 \\
0\end{array}$ & Valid \\
\hline & $\mathrm{X} 2.5$ & 0,437 & $\begin{array}{c}0,00 \\
0\end{array}$ & Valid \\
\hline & $\mathrm{X} 2.6$ & 0,483 & $\begin{array}{c}0,00 \\
0\end{array}$ & Valid \\
\hline & $\mathrm{X} 2.7$ & 0,685 & $\begin{array}{c}0,00 \\
0\end{array}$ & $\begin{array}{c}\text { Valli } \\
\text { d }\end{array}$ \\
\hline & $\mathrm{X} 2.8$ & 0,683 & $\begin{array}{c}0,00 \\
0\end{array}$ & $\begin{array}{c}\text { Valli } \\
\text { d }\end{array}$ \\
\hline & $\mathrm{X} 2.9$ & 0,602 & $\begin{array}{c}0,00 \\
0\end{array}$ & $\begin{array}{c}\text { Valli } \\
\text { d }\end{array}$ \\
\hline & $\begin{array}{c}\mathrm{X} 2.1 \\
0\end{array}$ & 0,645 & $\begin{array}{c}0,00 \\
0\end{array}$ & $\begin{array}{c}\text { Valli } \\
\text { d }\end{array}$ \\
\hline & $\begin{array}{c}\mathrm{X} 2.1 \\
1 \\
\end{array}$ & 0,695 & $\begin{array}{c}0,00 \\
0\end{array}$ & $\begin{array}{c}\text { Valli } \\
\text { d }\end{array}$ \\
\hline & $\begin{array}{c}\mathrm{X} 2.1 \\
2 \\
\end{array}$ & 0,548 & $\begin{array}{c}0,00 \\
0\end{array}$ & $\begin{array}{c}\text { Valli } \\
\text { d }\end{array}$ \\
\hline & $\begin{array}{c}\mathrm{X} 2.1 \\
3\end{array}$ & 0,563 & $\begin{array}{c}0,00 \\
0\end{array}$ & $\begin{array}{c}\text { Valli } \\
\text { d }\end{array}$ \\
\hline
\end{tabular}

Sumber : Data Diolah 2019

Berdasarkan hasil uji validitas dapat diketahui bahwa seluruh butir item pertanyaan memiliki nilai signifikansi lebih kecil dari 0,05, dengan demikian dapat dikatakan bahwa seluruh butir pertanyaan Standar Akuntansi Pemerintahadalah valid.

Tabel 4.3

Hasil Uji ValiditasAkuntabilitas Keuangan

\begin{tabular}{|l|c|c|c|c|}
\hline $\begin{array}{c}\text { Variab } \\
\text { el }\end{array}$ & $\begin{array}{c}\text { Ite } \\
\text { m }\end{array}$ & $\begin{array}{c}\text { Correla } \\
\text { tion }\end{array}$ & Sig & $\begin{array}{c}\text { Keter } \\
\text { angan }\end{array}$ \\
\hline Akunta & Y1 & 0,766 & 0,001 & Valid \\
\cline { 2 - 5 } bilitas & Y2 & 0,770 & 0,000 & Valid \\
\cline { 2 - 5 } Keuang & Y3 & 0,818 & 0,000 & Valid \\
\cline { 2 - 5 } an (Y) & Y4 & 0,627 & 0,000 & Valid \\
\cline { 2 - 5 } & Y5 & 0,770 & 0,000 & Valid \\
\cline { 2 - 5 } & Y6 & 0,778 & 0,000 & Valid \\
\cline { 2 - 5 } & Y7 & 0,760 & 0,000 & Valid \\
\cline { 2 - 5 } & Y8 & 0,743 & 0,000 & Valid \\
\cline { 2 - 5 } & Y9 & 0,645 & 0,000 & Valid \\
\hline
\end{tabular}




\begin{tabular}{|c|c|c|c|c|}
\hline \multirow{7}{*}{$\begin{array}{c}\text { Y1 } \\
0\end{array}$} & 0,825 & 0,000 & Valid \\
\cline { 2 - 5 } & $\begin{array}{c}\text { Y1 } \\
1\end{array}$ & 0,398 & 0,000 & Valid \\
\cline { 2 - 5 } & & & \\
21 & 0,816 & 0,000 & Valid \\
\hline $\begin{array}{c}\text { Y1 } \\
3\end{array}$ & 0,614 & 0,000 & Valid \\
\hline $\begin{array}{c}\text { Y1 } \\
4\end{array}$ & 0,588 & 0,000 & Valid \\
\hline $\begin{array}{c}\text { Y1 } \\
5\end{array}$ & 0,579 & 0,000 & Valid \\
\hline $\begin{array}{c}\text { Y1 } \\
6\end{array}$ & 0,563 & 0,000 & Valid \\
\hline
\end{tabular}

Sumber : Data Diolah 2019

Berdasarkan hasil uji validitas dapat diketahui bahwa seluruh butir item pertanyaan memiliki nilai signifikansi lebih kecil dari 0,05, dengan demikian dapat dikatakan bahwa seluruh butir pertanyaan adalah valid.

\section{Uji Reliabilitas}

Uji realiabilitas digunakan untuk mengukur kehandalan indikator. Jika angka reliabilitas Alpha Cronbach > 0,6 atau lebih besar dari 0,6, maka item variabel tersebut dinyatakan reliabel.

Tabel 4.4

Hasil Uji Reliabilitas

\begin{tabular}{|l|c|c|}
\hline \multicolumn{1}{|c|}{ Variabel } & $\begin{array}{c}\text { Alpha } \\
\text { Cronbach }\end{array}$ & Keterangan \\
\hline $\begin{array}{l}\text { Good } \\
\text { GovernanceX1 }\end{array}$ & 0,962 & Reliabel \\
\hline $\begin{array}{l}\text { Standar } \\
\text { Akuntansi } \\
\text { PemerintahX2 }\end{array}$ & 0,847 & Reliabel \\
\hline $\begin{array}{l}\text { Akuntabilitas } \\
\text { Keuangan Y }\end{array}$ & 0,942 & Reliabel \\
\hline
\end{tabular}

Sumber : Data Diolah 2019

Berdasarkan hasil uji relibiltas dapat diketahui bahwa seluruh variabel memiliki nilaiAlpha Cronbach lebih besar dari 0,6 dengan demikian dapat dikatakan bahwa seluruh variabel dinyatakan reliabel.

\section{Uji Asumsi Klasik}

1. Uji Multikolinearitas

Uji multikolineritas bertujuan menguji apakah dalam model regresi ditemukan adanya korelasi antar variabel bebas model regresi yang baik seharusnya tidak terjadi korelasi diantara variabel bebas jika variabel bebas berkorelasi maka variabel-variabel ini tidak ortogonal. Variabel ortogonal adalah variabel bebas yang nilai korelasi antar sesama variabel bebas $=0$. Multikolineritas dapat dilihat dari nilai Tolerance dan Variance Inflation Factor (VIF). Menurut Ghozali (2009), caramendeteksi terhadap adanya multikolineritas dalam model regresi adalah sebagai berikut:Besarnya Variabel Inflation Factor (VIF), pedoman suatu model regresi yang bebas Multikolineritas yaitu nilai VIF $\leq 10$.

Tabel 4.5

Hasil Uji

Multikolinearitas

\begin{tabular}{|c|r|r|c|}
\hline $\begin{array}{c}\text { Variabe } \\
\text { I }\end{array}$ & $\begin{array}{c}\text { Toleranc } \\
\boldsymbol{e}\end{array}$ & $\mathbf{V I F}$ & Keterangan \\
\hline $\mathrm{X} 1$ & 0,735 & $\begin{array}{r}1.36 \\
1\end{array}$ & $\begin{array}{c}\text { Tidak Terjadi } \\
\text { Multikolinearit } \\
\text { as }\end{array}$ \\
\hline $\mathrm{X} 2$ & 0,735 & $\begin{array}{r}1.36 \\
1\end{array}$ & $\begin{array}{c}\text { Tidak Terjadi } \\
\text { Multikolinearit } \\
\text { as }\end{array}$ \\
\hline
\end{tabular}

Sumber : Data Diolah 2019

Dari tabel diatas dapat disimpulkan hasil Uji Multikolinearitas melalui Variance Inflation faktor (VIF) pada hasil output SPSS model regresi ini bebas masalah dari Multikolinearitas karena masingmasing variabel independen memiliki VIF tidak lebih besar dari 10, maka pada hasil penelitian ini Tidak Terjadi Multikolinearitas

2. Uji Heterokedastisitas

Dalam pengujian heteroskedastisitas digunakan untuk menguji apakah dalam

JIEB, Jilid 6, No 3, November 2020 ISSN Online 2615-2134 
model regresi terjadi ketidaksamaan variance dari residual satu pengamatan ke pangamatan lain. Suatu penelitiandinyatakan bebas masalah heterokedastisitas jika data pada scatterplot menyebar tidak beraturan. Jika varian dari pengamatan lainya tetap, maka disebut homoskedasitas. Sedangkan apabila varianya berbeda dari suatu pengamatan ke pengamatan lainya disebut dengan gejala heterodasitas. Untuk mengetahui ada atau tidaknya gejala heterodasitas adalah dengan melihat ada tidaknya pola tertentu pada grafik scatter plot.

a. Titik - titik data menyebar diatas dan dibawah atau disekitar angka 0

b. Titik - titik tidak mengumpul hanya diatas atau dibawah saja

c. Penyebaran titik-titik data tidak boleh membentuk pola tertentu

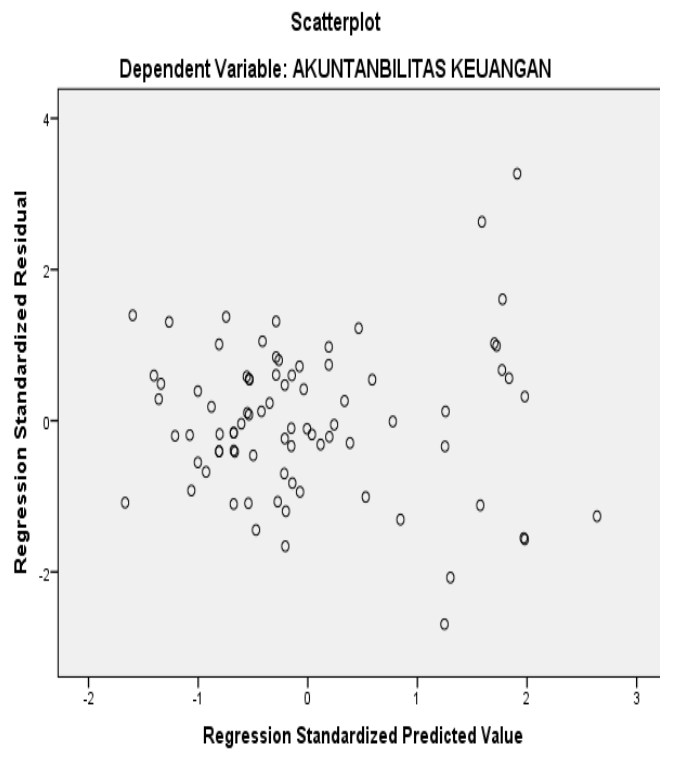

3. Uji Normalitas

Uji normalitas bertujuan untuk menguji apakah dalam model regresi, variabel pengganggu atau residual memiliki distribusi normal. Distribusi normal membentuk suatu garis lurus diagonal, dan ploting data residual akan dibandingkan dengan garis diagonalnya. Jika distribusi data normal, maka garis yang menggambarkan data sebenarnya akan mengikut garis normalnya (Ferdinand,2012) Suatu penelitian dinyatakan terdisitribusi normal, jika residualnya bergerak seiring dengan kurva normal.

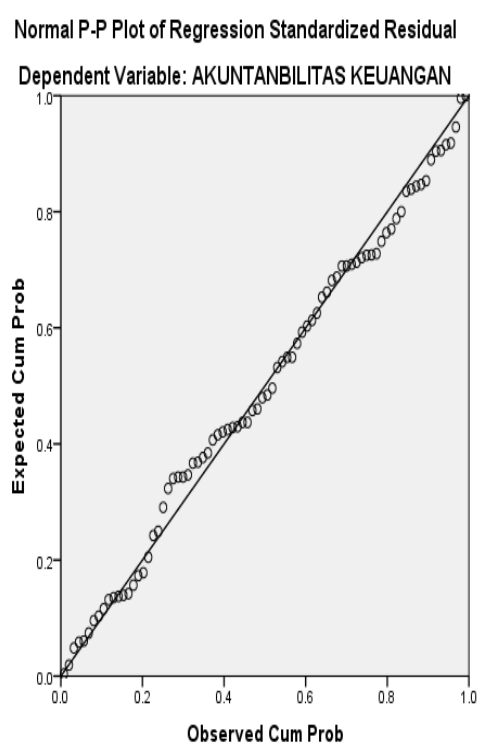

\section{Hasil Analisis Regresi Linier Berganda}

Persamaan regresi :

Tabel. 4.6

Persamaan Regresi

\begin{tabular}{|c|c|c|c|}
\hline \multicolumn{2}{|c|}{ Model } & \multirow{2}{*}{\multicolumn{2}{|c|}{$\begin{array}{l}\text { Unstandardize } \\
\text { d Coefficients }\end{array}$}} \\
\hline & & & \\
\hline & & $\mathrm{B}$ & Std. \\
\hline & & & Error \\
\hline \multirow{3}{*}{1} & (Constant) & 1.982 & 3.202 \\
\hline & $\begin{array}{l}\text { GOOD } \\
\text { GOVERNANCE }\end{array}$ & .460 & .112 \\
\hline & $\begin{array}{l}\text { STANDAR } \\
\text { AKUNTANSI } \\
\text { PEMERINTAH }\end{array}$ & .956 & .092 \\
\hline
\end{tabular}

Sumber : Data Diolah 2019

$\mathrm{Y}=1.9820,460 \mathrm{X} 1+0,956 \mathrm{X} 2+\mathrm{e}$

Dimana

$\mathrm{Y}=$ Akuntabilitas Keuangan

$\mathrm{X} 1=$ Good Governance

X2= Standar Akuntansi Pemerintah

1. Nilai koefisien regresi variabel Good Governance (X1) 0,460 adalah positif, yang berarti bahwa adanya hubungan

JIEB, Jilid 6, No 3, November 2020 ISSN Online 2615-2134 
searah antara variabel bebas dan variabel terikat, semakin nilai koefisen (nilai Sig) pada Good Governance tinggi, maka hubungan akuntanbilitas keuangan juga akan meningkat sebesar $46 \%$

2. Nilai koefisien regresi variabel Standar Akuntansi Pemerintah(X2) 0,956adalah positif, yang berarti bahwa adanya hubungan searah antara variabel bebas dan variabel terikat, semakin nilai koefisen (nilai Sig) pada Standar Akuntansi Pemerintah, maka hubungan akuntanbilitas keuangan juga akan meningkat sebesar $12,7 \%$

\section{Uji Hipotesis}

Sebagaimana telah dirumuskan sebelumnya bahwa dalam penelitian ini sesuai dengan hipotesis :

\section{Uji F}

Uji statistik $F$ pada dasarnya menunjukkan apakah semua variabel independen atau bebas yang dimasukkan dalam model mempunyai pengaruh secara bersamasama terhadap variabel dependen atau terikat. Artinya, semua variabel independen secara simultan merupakan penjelas yang signifikan terhadap variabel dependen (Ferdinand,2012). Hasil nilai signifikansi pengujian (Sig.F) sebagai berikut :

Tabel.

\begin{tabular}{|c|c|c|c|c|c|c|}
\hline \multicolumn{2}{|c|}{ Model } & \multirow{2}{*}{$\begin{array}{c}\begin{array}{c}\text { Sum } \\
\text { of } \\
\text { Square } \\
\text { S }\end{array} \\
4135.9 \\
04\end{array}$} & \multirow{2}{*}{$\begin{array}{r}\mathrm{df} \\
\\
2\end{array}$} & $\begin{array}{c}\text { Mean } \\
\text { Squar } \\
\mathrm{e}\end{array}$ & F & Sig. \\
\hline \multirow{2}{*}{1} & $\begin{array}{l}\text { Regre } \\
\text { ssion }\end{array}$ & & & $\begin{array}{r}2067 . \\
952\end{array}$ & $\begin{array}{r}115 . \\
162\end{array}$ & $\begin{array}{r}.000 \\
\mathrm{~b}\end{array}$ \\
\hline & $\begin{array}{l}\text { Resid } \\
\text { ual }\end{array}$ & $\begin{array}{r}1418.5 \\
96\end{array}$ & 79 & $\begin{array}{r}17.95 \\
7\end{array}$ & & \\
\hline
\end{tabular}

\begin{tabular}{|l|l|r|r|l|l|l|}
\hline & Total & 5554.5 & 81 & & & \\
& 00 & & & & \\
\hline
\end{tabular}

Sumber : Data Diolah 2019

\section{Uji t}

Uji t Digunakan untuk menghitung signifikasi pengaruh secara parsial atau dari masing-masing variabel $\mathrm{X}$ terhadap Y, (Ferdinand, 2012). Hasil nilai signifikansi pengujian (Sig.t) sebagai berikut :

Tabel 4.8

\section{Hasil Uji t}

\begin{tabular}{|c|c|c|c|c|}
\hline \multirow{2}{*}{\multicolumn{2}{|c|}{ Model }} & \multirow{2}{*}{$\begin{array}{c}\text { Standardi } \\
\text { zed } \\
\text { Coefficie } \\
\text { nts } \\
\text { Beta }\end{array}$} & \multirow[t]{2}{*}{$\mathrm{t}$} & \multirow{2}{*}{ Sig. } \\
\hline & & & & \\
\hline \multirow{6}{*}{1} & (Constant) & & .619 & $\begin{array}{r}.53 \\
8\end{array}$ \\
\hline & GOOD & .273 & 4.122 & .00 \\
\hline & $\begin{array}{l}\text { GOVERNAN } \\
\text { CE }\end{array}$ & & & 0 \\
\hline & STANDAR & \multirow[t]{3}{*}{.690} & 10.39 & \multirow{3}{*}{$\begin{array}{r}.00 \\
0\end{array}$} \\
\hline & AKUNTANSI & & 8 & \\
\hline & $\begin{array}{l}\text { PEMERINTA } \\
\mathrm{H}\end{array}$ & & & \\
\hline
\end{tabular}

Sumber : Data Diolah 2019

Berdasarkan hasil uji $t$ yang tercantum pada tabel diatas dapat dilihat bahwa:

a. Variabel X1 Good Governance didapatkan nilai sig. $=0.000$ (Nilai Sig. < 0,05) artinya secara parsial berpengaruh terhadap variabel terikat akuntanbilitas keuangan.

b. Variabel X2 Standar Akuntansi Pemerintahdidapatkan nilai sig. $=$ 0.000 (Nilai Sig. $<0,05$ ) artinya secara parsial berpengaruh terhadap variabel terikat akuntanbilitas keuangan.

\section{Uji Dominan}

JIEB, Jilid 6, No 3, November 2020 ISSN Online 2615-2134 
Pengujian variabel bebas yang dominan mempengaruhi variabel terikat dalam satu model regresi linier berganda dengan menggunakan nilai Standardized Coefficients Beta. Dengan penentuan hasil, semakin tinggi nilai Beta, maka semakin besar pengaruhnya terhadap variabel terikat.

Tabel 4.9

Stadardized Coenfficients

\begin{tabular}{|c|r|l|l|}
\hline $\begin{array}{c}\text { Variabe } \\
\mathbf{I}\end{array}$ & $\begin{array}{c}\text { Standardize } \\
\mathbf{d} \\
\text { Coefficients }\end{array}$ & $\mathbf{t}$ & Sig. \\
\cline { 2 - 4 } & $\mathrm{B}$ & & \\
\hline $\mathrm{X} 1$ & .273 & 4.122 & 000 \\
\hline $\mathrm{X} 2$ & .690 & $\begin{array}{l}10.39 \\
\mathrm{n}\end{array}$ & 0 \\
\hline
\end{tabular}

Sumber : Data Diolah 2019

Berdasarkan tabel diatas, dapat diketahui bahwa variabel X1 memiliki nilai standarized coefficient sebesar 0,273 dan variabel X2 memiliki nilai 0,690, dengan demikian variabel yang berpengaruh dominan terhadap akuntanbilitas keuangandari adalah variabel standar akuntansi pemerintah (X2).

Koefisien Determinasi

Tabel 4.10

Model Summary

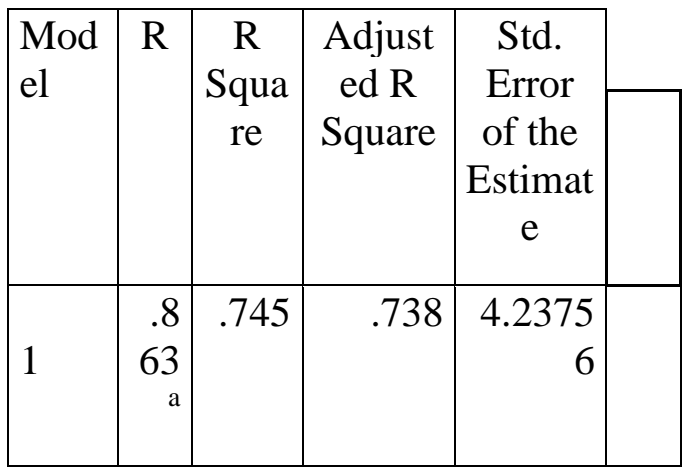

Sumber : Data Diolah 2019
Tabel model summary terlihat nilai Nilai $\mathrm{R}$ dengan nilai sebesar 0,863 atau $86,3 \%$ adalah koefisien korelasi yang menunjukkan tingkat hubungan antara variabel $\mathrm{X} 1$ dan $\mathrm{X} 2$, dengan variableY. Nilai korelasi tersebut menunjukkan tingkat hubungan sangat kuat karena berada di antara 0,800 sampai dengan 1,000 .

Tabel 4.11

Tabulasi interprestasi nilai $\mathrm{R}$

\begin{tabular}{|c|c|c|}
\hline No & $\begin{array}{c}\text { Interval } \\
\text { Koefisien }\end{array}$ & $\begin{array}{c}\text { Tingkat } \\
\text { Hubungan }\end{array}$ \\
\hline 1 & $0,800-1,000$ & Sangat Kuat \\
\hline 2 & $0,600-0,799$ & Kuat \\
\hline 3 & $0,400-0,599$ & Sedang \\
\hline 4 & $0,200-0,399$ & Rendah \\
\hline 5 & $0,000-0,199$ & $\begin{array}{c}\text { Sangat } \\
\text { Rendah }\end{array}$ \\
\hline
\end{tabular}

Sumber : Sugiyono (2014)

Tabel model summary terlihat nilai $\mathrm{R}$ Square sebesar 0.745 atau dengan kata lain $74,5 \%$ artinya model penelitian mampu menjelaskan dari perubahan Akuntabilitas Keuangan. Sedangkan sisanya (100\%$74,5 \%=25,5 \%$ ) dijelaskan oleh faktor lain.

\section{Pembahasan}

1. Pengaruh Secara Simultan Penerapan Good Governance Dan Standar Akuntansi Pemerintah Terhadap Akuntabilitas Keuangan Kecamatan Di Kabupaten Barito Kuala

Uji statistik $F$ atau simultan menunjukkan apakah semua variabel bebas yang dimasukkan dalam model mempunyai pengaruh secara bersamasama terhadap variabel terikat. Pengujian dilakukan dengan signifikansi atau tidak, maka dugunakan probility sebesar 5\% dalam arti $(\alpha=0.05)$. 
Hasil penelitian dan dilakukan uji $\mathrm{F}$ di atas bahwa nilai probality signifikan secara simultan adalah lebih kecil dari 0,005 maka dapat disimpulkan Secara Simultan Penerapan Good Governance Dan Standar Akuntansi Pemerintah Terhadap Akuntabilitas Keuangan Kecamatan Di Kabupaten Barito Kuala dengan nilai sig 0,000 berdasarkan hasil uji F

Sehingga hipotesis pertama yang berbunyi Secara Simultan Penerapan Good Governance Dan Standar Akuntansi Pemerintah Terhadap Akuntabilitas Keuangan Kecamatan Di Kabupaten Barito Kuala dapat diterima atau teruji. Penelitian ini konsisten dengan penelitian yang dilakukan oleh Fauzia Kartika Darmanto, 2017, dengan hasil penelitian variabel good governance berpengaruh positif dan signifikan terhadap akuntabilitas keuangan.

Penelitian ini memberikan tambahan referensi hasil studi terkait sumber referensi bagi pengembangan ilmu penelitian dibidang pemasaran. Selain itu penelitian ini diharapkan mampu menambah wawasan terkait dengan Penerapan Good Governance dan Standar Akuntansi Pemerintah Terhadap Akuntabilitas Keuangan. Good Government Governance juga didukung dengan adanya prinsip responsibilitas yakni adanya pelaksanaan kegiatan-kegiatan organisasi yang telah disusun sebelumnya berdasarkan peraturan dan kebijakan yang berlaku. Standar Akuntansi Pemerintahan dalam menyusun dan menyajikan laporan keuangan mempunyai pilihan dua basis, yaitu SAP berbasis akrual.
2. Pengaruh Secara Parsial Penerapan Good Governance Dan Standar Akuntansi Pemerintah Terhadap Akuntabilitas Keuangan Kecamatan Di Kabupaten Barito Kuala

Dari hasil pengujian data dapat diketahui Uji $\mathrm{t}$ untuk menguji signifikansi konstanta dan variabel dependen terlihat pada angka sig (signifikansi atau besaran nilai probabilitas). Pengujian dilakukan dengan membandingkan nilai probality signifikansi dengan probality sebesar $5 \%$ dalam arti $(\alpha=0.05)$.

PengaruhPenerapan Good Governance Terhadap Akuntabilitas Keuangan Kecamatan Di Kabupaten Barito Kuala. Pada tabel diatas memiliki nilai probality signifikansi yaitu lebih kecil dari 0,05 sehingga dapat disimpulkan variabel Penerapan Good Governance berpengaruh signifikan terhadap Akuntabilitas Keuangan Kecamatan Di Kabupaten Barito Kuala secara parsial dengan nilai sig 0.000lebih kecil dari 0,05 . Dengan demikian hipotesis yang berbunyi Penerapan Good Governanceberpengaruh signifikan secara parsial terhadap Akuntabilitas Keuangan Kecamatan Di Kabupaten Barito Kualadapat diterima atau terujiberdasarkan hasil uji t.

Hal ini berarti pelaksanaan Penerapan Good Governanceatau Pemerintahan yang baikdijalankan dengan mengikuti prinsip-prinsip pengelolaan yang baik, seperti transparansi, akuntabilitas, partisipasi, keadilan dan kemandiri, sehingga sumber daya yang ada dalam pengelolaan pemerintah Kecamatan Di Kabupaten Barito Kualabenar-benar mencapai tujuan sebesar-besarnya untuk kemakmuran dan kemajuan rakyat.

JIEB, Jilid 6, No 3, November 2020 ISSN Online 2615-2134 
Penerapan Good Governanceatau Pemerintahan yang baik juga didukung dengan adanya prinsip responsibilitas yakni adanya pelaksanaan kegiatankegiatan organisasi yang telah disusun sebelumnya berdasarkan peraturan dan kebijakan yang berlaku. Selanjutnya adanya prinsip independensi yakni dalam melaksanakan kegiatan organisasi tidak adanya intervensi atau pengaruh dari pihak lain. Penelitian ini konsisten dengan penelitian yang dilakukan oleh Fauzia Kartika Darmanto, 2017, dengan hasil penelitian variabel good governance berpengaruh positif dan signifikan terhadap akuntabilitas keuangan.

PengaruhStandar

Akuntansi Pemerintah Terhadap Akuntabilitas Keuangan Kecamatan Di Kabupaten Barito Kuala. Pada tabel diatas memiliki nilai probality signifikansi yaitu lebih kecil dari 0,05 sehingga dapat disimpulkan variabel Standar Akuntansi Pemerintah berpengaruh signifikan terhadap Akuntabilitas Keuangan Kecamatan Di Kabupaten Barito Kuala secara parsial dengan nilai sig 0.000lebih kecil dari 0,05. Dengan demikian hipotesis yang berbunyi Standar Akuntansi Pemerintah berpengaruh signifikan secara parsial terhadap Akuntabilitas Keuangan Kecamatan Di Kabupaten Barito Kualadapat diterima atau terujiberdasarkan hasil uji t.

Hal ini berarti kemampuan diri dalam mengerti atau mengetahui dengan benar terhadap sesuatu (Standar Akuntansi Pemerintahan), mempunyai wawasan dan pengertian pengetahuan yang mendalam mengenai standar akuntansi pemerintah.

Adapun alasanhasil penelitian berpengaruh dapat diketahui Pemerintah menerapkan Standar Akuntansi Pemerintahan dalam menyusun dan menyajikan laporan keuangan mempunyai pilihan dua basis, yaitu SAP berbasis akrual. Penerapan SAP berbasis akrual dalam lingkungan pemerintahan adalah untuk mengetahui seberapa besarnya biaya yang diperlukan untuk menghasilkan pelayanan untuk kepentingan publik. Dengan adanya SAP berbasis akrual ini dapat menghasilkan informasi keuangan berupa laporan keuangan pemerintah daerah yang bersifat relevan, andal, dapat dibandingkan, dan dapat dipahami untuk pengambilan suatu keputusan baik ekonomi, sosial, maupun politik.

Suatu pemerintahan yang menerapkan Standar Akuntansi Pemerintahan akan menghasilkan laporan keuangan yang sangat diperlukan dalam lingkungan pemerintahan. Dengan Standar Akuntansi Pemerintahan diharapkan agar semuanya berjalan dengan terstruktur dan sesuai dengan pedoman yang berlaku sehingga akan dihasilkan laporan keuangan yang berkualitas dan akurat terutama laporan keuangan yang keberadaannya sangat penting dan dibutuhkan untuk dipertanggungjawabannya

Penelitian ini konsisten dengan penelitian yang dilakukan oleh Fauzia Kartika Darmanto, 2017, dengan hasil penelitian variabel standar akuntansi pemerintah berpengaruh positif dan signifikan terhadap akuntabilitas keuangan.

3. Variabel yang berpengaruh dominan terhadap Akuntabilitas Keuangan Kecamatan Di Kabupaten Barito Kuala

JIEB, Jilid 6, No 3, November 2020 ISSN Online 2615-2134 
Hipotesis ketiga Harga Diduga

Standar Akuntansi Pemerintah berpengaruh dominan Terhadap Akuntabilitas Keuangan Kecamatan Tabukan Kabupaten Barito Kuala.Dari hasil pengujian dapat diketahui berdasarkan uji $\mathrm{t}$ standarized coefficientvariabelStandar Akuntansi Pemerintahberpengaruh dominan terhadap Akuntabilitas Keuangan Kecamatan Tabukan Kabupaten Barito Kualasehingga hipotesis diterima.

\section{PENUTUP}

\section{Kesimpulan}

1. Secara Simultan Penerapan Good Governance Dan Standar Akuntansi Pemerintah berpengaruh signifikan Terhadap Akuntabilitas Keuangan Kecamatan Di Kabupaten Barito Kuala.

2. VariabelPenerapanGood Governance berpengaruh signifikan terhadap Akuntabilitas Keuangan Kecamatan Di Kabupaten Barito Kuala secara parsial.Variabel Standar kuntansi Pemerintah berpengaruh signifikan terhadap Akuntabilitas Keuangan Kecamatan Di Kabupaten Barito Kuala secara parsial.

3. Variabel Standar Akuntansi Pemerintah berpengaruh dominan terhadap Akuntabilitas Keuangan Kecamatan Tabukan Kabupaten Barito Kuala

\section{Saran}

1. Berdasarkan hasil penelitian standar akuntansi pemerintahan memiliki pengaruh yang sangat baik untuk meningkatkan akuntabilitas keuangan Kecamatan Di Kabupaten Barito Kuala, oleh karena itu sebaiknya Kecamatan Di Kabupaten Barito Kuala lebih mengoptimalkan penerapan tandar akuntansi pemerintahan dengan cara meningkatkan mutu sumber daya manusia, misalnya dengan mengadakan sosialisasi PP Nomor 71 Tahun 2010 tentang Standar Akuntansi Pemerintahan.

2. Berdasarkan hasil penelitian hubungan good governance memiliki pengaruh signifikan terhadap akuntanbilitas keuangan Kecamatan Di Kabupaten Barito Kuala hendaknya lebih meningkatkan tingkat partisipasi kepada para pegawai, pers, ataupun masyarakat, yaitu dengan mengikutsertakan pers dan masyarakat dalam setiap kegiatan yang ada, dan memberikan penghargaan kepada pegawai yang melaksanakan tugas dengan baik, sebaliknya memberikan sanksi kepada pegawai yang lalai dalam melaksanakan tugas.

3. Berdasarkan hasil penelitian hubungan standar akuntansi memiliki pengaruh signifikan terhadap akuntanbilitas keuangan Kecamatan Di Kabupaten Barito Kuala, dengan demikian, untuk indikator-indikator baik dari seg standar akuntansi pemerintahan maupun good governance dengan nilai terendah, sebaiknya terus dioptimalkan untuk menghasilkan akuntabilitas keuangan Kecamatan Di Kabupaten Barito Kuala yang baik karena akuntabilitas keuangan Kecamatan Di Kabupaten Barito Kuala akan mempengaruhi akuntabilitas keuangan Kecamatan Di Kabupaten Barito Kuala

4. Bagi Kecamatan Di Kabupaten Barito Kuala, diharapkan lebih meningkatkan lagi penerapan prinsip-prinsipGood Governance agar stakeholder dapat dengan mudah mengakses informasi laporan keuangan karena telah terciptanya transparansi dan akuntabel laporankeuangan 
5. Bagi Kecamatan Di Kabupaten Barito Kuala, diharapkan dapat melaksanakan system akuntansi pemerintahan dengan baik melalui peningkatan sumber daya manusia pengelola keuangan, memperkuat budaya kerja melalui peningkatan motivasi dan perilaku untuk lebih mengutamakan orientasi pekerjaan pada pelayanan publik, terhadap akuntabilitas keuangan dan kinerja pemerintah melalui pendidikan dan pelatihan serta workshop dan pemberian insentif yang sesuai serta mengupayakan peningkatan kualitas dan kuantitas reward and punishment berdasarkan pencapaian kinerja pegawai

6. Bagi peneliti selanjutnya, penambahan variabel lain selain variabel-variabel dalam penelitian ini sangat disarankan untuk menemukan hasil pengujian dan pengetahuan baru, khususnya variabelvariabel yang mendukung penelitianini

\section{DAFTAR PUSTAKA}

Abdul Halim, 2012, Akuntansi Sektor Publik Akuntansi Keuangan Daerah. Edisi 4. Penerbit Salemba Empat. Jakarta

Augusty, Ferdinand. (2013). Metode Penelitian Manajemen. Semarang. Badan Penerbit Universitas Diponegoro

Bastian, Indra, 2012, Sistem Akuntansi Sektor Publik, penerbit salemba empat ,Jakarta

Elvira Zeyn, 2011, Pengaruh Penerapan Good Governance dan Standar Akuntansi Pemerintahan terhadap Akuntabilitas Keuangan. http://digilib.mercubuana.ac.id/mana ger/t!@file_artikel_abstrak/Isi_Artik
el_522894149282.pdfDiakses pada Tanggal 26 Mei 2019

Fauzia Kartika Darmanto , 2017, Pengaruh Penerapan Good Governance, Audit Kinerja Dan Standar Akuntansi Pemerintah Terhadap Akuntabilitas Keuangan Pemerintah Daerah Kabupaten Karanganyar. http://eprints.ums.ac.id/55153/11/NA SKAH\%20PUBLIKASI.pdfDiakses pada Tanggal 26 Mei 2019

Ghozali, Imam. 2014. Structural Equation Modeling, Metode Alternatif dengan Partial Least Square (PLS). Edisi 4. Semarang : Badan Penerbit Universitas Diponegoro

Peraturan Presiden Republik Indonesia Nomor 29 Tahun 2014 Tentang Sistem Akuntabilitas Kinerja Instansi Pemerintah

Peraturan Pemerintah Nomor 24 tahun 2005 tentang Standar Akuntansi Pemerintahan

Peraturan Pemerintah Nomor 8 Tahun 2006 tentang Pelaporan Keuangan dan Kinerja Instansi Pemerintah (Lembaran Negara Republik Indonesia Tahun 2006 Nomor 26, Tambahan Lembaran Negara Republik Indonesia Nomor 4614)

Peraturan Pemerintah Nomor 71 tahun 2010 tentang Standar Akuntansi Pemerintahan

Penny Kusumastuti, 2014, Akuntansi Sektor Publik, Salemba Empat, Jakarta

Priyatno, Duwi. 2016. Belajar Alat Analisis Data Dan Cara Pengolahnnya Dengan SPSS Praktis dan Mudah Dipahami untuk Tinkat Pemula dan Menengah. Yogyakarta: Gava Media 
Koiman, 2014, Mewujudkan Good Governance Melalui Pelayanan Publik, Yogyakarta: Gajah Mada Universty Press

Mahmudi, (2013), Manajemen Kinerja Sektor Publik. Sekolah Tinggi IlmuManajemen YKPN, Yogyakarta

Mardiasmo. 2013. Perpajakan Edisi Revisi, Andi Offset, Yogyakarta

Sedarmayanti, 2013, Manajemen Sumber Daya Manusia, Bandung: Refika Aditama.

Sugiyono. 2014. Metode Penelitian Pendidikan Pendekatan Kuantitatif, Kualitatif Dan $R \& D$. Bandung: Alfabeta

Sugiyono. 2015. Metode Penelitian Pendidikan (Pendekatan Kuantitatif, Kualitatif dan R\&D). Penerbit CV. Alfabeta: Bandung

Suharsimi Arikunto. 2014. Prosedur Penelitian Suatu Pendekatan Praktik. Jakarta : Rineka Cipta
Undang-Undang Dasar Negara Republik Indonesia Tahun 1945

Undang-Undang Nomor 1 Tahun 2004 tentang Perbendaharaan Negara (Lembaran Negara Republik Indonesia Tahun 2004 Nomor 5, Tambahan Lembaran Negara Republik Indonesia Nomor 4355)

Ulum, Ihyaul, 2013. Akuntansi Sektor Publik, Graha Ilmu, Yogyakarta

Verra Aprillia Nurussalam, 2015, Pengaruh Penerapan Good Governance Dan Standar Akuntansi Pemerintahan Terhadap Kualitas Laporan Keuangan Pemerintah Daerah (Studi Survei Pada Pemerintah Daerah Kabupaten Bandung Barat, Pemerintah Daerah Kota Bandung, dan Pemerintah Daerah Provinsi Jawa Barat)https://repository.widyatama.a c.id/xmlui/bitstream/handle/1234567 89/2327/0109432.pdfDiakses pada Tanggal 26 Mei 2019 